\title{
Nutritional characteristics of important desert grasses $i$ Saudi Arabia
}

\author{
UNAB G. BOKHARI, FAISAL ALYAEESH, AND MOHMOOD AL-NOORI
}

\begin{abstract}
A few representative dominant grasses were studied from various regions in Saudi Arabia to evaluate their nutritional and survival characteristics under the harsh growing environment of the Kingdom. Desert grasses are the main sources of nutrients for pastoral grazing animals. Analyses of representative samples indicated high protein and carbohydrate contents in various parts of the plants. However, these nutrients are available only for a short duration and are below sufficiency level for many milk and meat animals during much of the growing season.
\end{abstract}

Key Words: Panicum turgidum, Hyperrhenia hirta, Andropogon distachyos, Stipagrostis plumosa, protein, carbohydrates

The importance of grasses as a source of nutrients for pastoral grazing animals cannot be overemphasized in Saudi Arabia, where more than $90 \%$ of the total land mass is considered rangeland. No ecological study has been done in Saudi Arabia to delineate plant communities with respect to species diversity, density, dominance, and nutritional characteristics except for some preliminary information available in the local literature (Zahran, no date given). Forbs, shrubs, and grasses provide sufficient dry matter for grazing animals during normal growing season. However, grasses usually have a greater impact on the productivity of grasslands in arid or semiarid areas. Most of the area in Saudi Arabia is characterized as arid with high temperature, low rainfall, and high soil salinity. Grasslands vegetation is frequently subjected to extreme drought and heat. However, a number of grass species have developed strategies over the years to adapt to the harsh environment of the Kingdom (Bokhari et al. 1987).

Since nutritional characteristics of desert grasses in the Kingdom have not been studied in detail, this study evaluated nutritional qualities of dominant grasses from various regions in the Kingdom.

\section{Site Descriptions}

Elevation, mean annual rainfall, average annual temperature, and the electrical conductivity and organic matter content of the soils of the central, eastern, and the southwestern study regions are given in Table 1. Locations within each region were chosen based on visual observations of diversity and abundance of vegetation, delimited either by sparse trees (in the case of the southwestern region) or by bare-denuded areas (in the case of central and eastern regions).

Generally, the central region was characterized by extremely high temperatures, low rainfall, low humidity, and low soil salinity. Eastern region had high temperatures, high relative humidity, low rainfall, and high soil salinity. Southwestern region, at 1,700-2,800 meters, was characterized by low temperatures, low relative humidity, high rainfall and low soil salinity. These regions represent contrasting soil and climatic conditions prevailing in many areas of the Kingdom.

\footnotetext{
Senior author is plant physiologist with US/Saudia Arabian Joint Commission on Economic cooperation. Second and third authors are research associates, Department of Crop Production Section, Regional Agriculture and Water Research Center, P.O. Box 17285, Riyadh, Saudi Arabia.

Manuscript accepted 28 June 1989.
}

Table 1. General characteristics of the study sites.

\begin{tabular}{lccccc}
\hline \hline Region/location & $\begin{array}{c}\text { Elevation } \\
\text { above sea } \\
\text { level }\end{array}$ & $\begin{array}{c}\text { Annual } \\
\text { rainfall }\end{array}$ & $\begin{array}{c}\text { Annual } \\
\text { temp. }\end{array}$ & $\begin{array}{c}\text { Soil1 } \\
\text { EC }\end{array}$ & $\begin{array}{r}\text { Organ } \\
\text { matte }\end{array}$ \\
\hline Central/Riyadh & $600-645$ & $110-125$ & $20-25$ & 5.40 & 0.42 \\
Eastern/Damman & $20-25$ & $60-75$ & $20-26$ & 8.50 & 0.53 \\
Southwestern/ & $1400-2800$ & $150-655$ & $16-22$ & 2.25 & 0.77 \\
Abha & & & & & \\
\hline
\end{tabular}

IElectrical conductivity was determined in soil extract from saturated paste us Amber Solution Analyzer.

2Organic matter was determined by the Walkley-Black Procedure.

\section{Methods}

Within each location 2 plots of $500 \mathrm{~m} \times 2,000 \mathrm{~m}$ were chosen determination of dominant species. Dominance of a particu species was determined by visual observation of abundance intervals of $100 \mathrm{~m}$ along the length of the $500 \mathrm{~m} \times 2,000-\mathrm{m} \mathrm{pl}$ Each species selected as dominant was sampled by pulling out whole plant with roots. Each plant was separated into shoc roots, crowns, or rhizomes. Shoots of each plant were either sep ated into leaves, nodes, internodes, and stem including flower: parts or analyzed as whole plant-above ground biomass. Samp were collected at different times of the growing season to coinc with various phenological stages.

Samples were dried in a forced-air oven at $70^{\circ} \mathrm{C}$ for $72 \mathrm{hov}$ ground through 40-mesh screen in a Wiley mill and stored in plas vials for future chemical analyses. Samples were analyzed for $~$ matter, protein and carbohydrates contents. Protein was det mined by the kjeldahl method for total $N \times 6.25$ and total $n$ structural carbohydrates (TNC) were determined by the proced 1 outlined by Smith (1969).

\section{General Characteristics of Grasses in the Study Panicum turgidum}

It is a glaucous perennial plant with deep fibrous root system a reaches a height of $100-150 \mathrm{~cm}$. The vegetative growth is $\mathrm{v}$ rapid. Within a few weeks following precipitation it produ abundant, palatable biomass. During the reproductive period, spikelets on older branches mature and seed is scattered by desert wind, while younger branches continue producing spikel which usually weather prematurely due to insufficient moisturs the soil. Panicum turgidum is usually found in association $\mathrm{w}$ Lasiurus species in Saudi Arabia in the central and eastern regi

\section{Hyperrhenia hirta}

It is a tufted perennial with a dense fibrous root system a flowering branches reach up to $180 \mathrm{~cm}$ in height. It grows elevations of 1,800-2,500 $\mathrm{m}$ in the southwestern region on stc and rocky sites. Plants are quite drought resistant and can end drought for many weeks, but will resume growth at the onset of a precipitation event. It grows in association with Cenchrus cilia. Aristida sahelica, and Andropogon distachyus. 


\section{Stipagrostis plumosa}

It is usually perennial with strong roots and attains a height of up to $40-50 \mathrm{~cm}$. It propagates through seeds in loose or stabilized sands overlying sandstone and is found in association with Panicum turgidum, Lasiurus hirsutus, and Pennisetum dichotomum. It is palatable to sheep, goats, and camels.

\section{Andropogon distachyos}

It is a tufted perennial with culms attaining $25-100 \mathrm{~cm}$ height, leaf blades $7-20 \mathrm{~cm}$ long and $1-5 \mathrm{~mm}$ wide. It grows on dry slopes in mountain grassland at elevation of $1,700-3,000 \mathrm{~m}$. It grows in association with Hyperrhenia hirta, Themeda triandra, and Eragrostis braunii, in the southwestern region of Saudi Arabia.

\section{Results and Discussion}

Table 2 shows the whole plant protein content of 4 species at 2 stages, first when it is $90 \%$ green and second when it is $100 \%$ yellow.

Table 2. Protein contents of dominant native grasses.

\begin{tabular}{lccc}
\hline \hline Species & $\begin{array}{c}\text { Whole plant } \\
\text { 90\% green }\end{array}$ & $\begin{array}{c}\text { Whole plant } \\
\text { 100\% yellow }\end{array}$ & LSD 0.05 \\
\hline & $\ldots \ldots \ldots .$. & \\
Panicum turgidum & 9.5 & 4.2 & 1.8 \\
Hyperrhenia hirta & 7.3 & 3.4 & 1.0 \\
Andropogon distachyos & 5.9 & 2.3 & 0.6 \\
Stipagrostis plumosa & 4.9 & 2.7 & 0.9 \\
LSD 0.05 & 1.2 & 0.6 & \\
\hline
\end{tabular}

Panicum turgidum has significantly more protein at green and yellow stages than the other 3 species. $H$. hirta, which grows at higher elevations, also contains more protein than $A$. distachyus and $S$. plumosa. The protein content at the yellow stage is comparable to that of other grass species at similar growth stages from other locations (Reid et al. 1979, Coward-Lord et al. 1974).

$P$. turgidum appears to accumulate large amounts of nitrogen in its above-ground parts and this amount is substantially higher than that of many species growing under rangeland conditions (Yadava 1980). Where this nitrogen comes from is not clear. Most of the associated desert soils contain almost negligible amounts of nitrogen. Fixation of atmospheric nitrogen by desert grasses has not been studied. The organic matter content of soil within a 1-meter radius of the plant was significantly higher (1.5\%) than that of the soil beyond this range $(0.3 \%)$. Due to frequent windy conditions, dry matter from the adjacent area is blown and gets trapped in the whorl-like canopy of $P$. turgidum. This may be the main source of nitrogen supply to these plants. Under the extreme climatic conditions, dry matter disappearance is very fast. Although productivity on a unit of land area is very low, there is always abundant biomass available following rainfall due to the multitude of both annual and perennial plants which contribute to the dry matter accumulated in the vicinity of $P$. turgidum plants. The possibility of nitrogen input into the soil $\left(0.45 \mathrm{KG} \mathrm{N}^{-h^{-1}} \cdot\right.$ yearl $\left.^{1}\right)$ through precipitation is negligible (Handy and Tucker 1984).

$H$. hirta usually grows in rocky areas in small crevices or in cracks in the rocks where run-off rain water accumulates. Run-off water washes minerals from the parent rock materials and accumulation continues in the crevices, which supplies nutrients to the individual plant growing on that site.

$A$. distachyos has developed a strategy similar to $H$. hirta for survival and continued propagation. Mature seeds get trapped within the crevices between rocks and germinate as soon as there is even a small amount of rain water available.

$S$. plumosa, which grows profusely in loose or stabilized sand, contains very low protein and is not very palatable to sheep and goats. Camels graze the top portion of the seed stalks and leave the
Table 3. Protein contents of different components of native grasses.

Inter- LSD

\begin{tabular}{|c|c|c|c|c|c|c|c|}
\hline Species & Leaves & Stem & Roots. & Crown & Nodes & $\begin{array}{l}\text { Inter- } \\
\text { nodes }\end{array}$ & $\begin{array}{l}\text { LSD } \\
0.05\end{array}$ \\
\hline & $\ldots . .$. & & $\ldots \%$ & $-\ldots$ & (n) & & \\
\hline Panicum turgidum & 8.8 & 6.1 & 4.4 & 5.9 & 7.6 & 4.1 & 1.1 \\
\hline Hyperrhenia hirta & 7.9 & 4.9 & 3.5 & 4.5 & 2.5 & 2.4 & 0.6 \\
\hline Andropogon distachyos & 6.3 & 4.3 & 2.5 & 2.7 & 1.9 & 1.6 & 0.5 \\
\hline Stipagrostis plumosa & 5.4 & 4.1 & 3.3 & 2.5 & 2.1 & 2.0 & 0.5 \\
\hline LSD $0.05=$ & 1.5 & 0.8 & 0.5 & 0.4 & 0.6 & 0.4 & \\
\hline
\end{tabular}

rest for weathering and decomposition.

Table 3 shows the protein of different parts of various species. Leaves of all species contain significantly more protein than the other parts. $P$. turgidum contains more protein in all its parts than the same parts from other species. Nodes of $P$. turgidum are quite rich in protein and serve as a source of reserve energy either for translocation to other parts or for regrowth if propagated vegetatively. Crowns and roots also contain substantial amounts of protein to be used during regrowth under favorable climatic conditions following grazing. These results indicate the strategy developed by desert vegetation for survival by economizing on reserve food materials in different storage organs instead of utilizing all of them for current growth. $H$. hirta seems to be a rich source of protein for grazing animals in the Asir province along with $A$. distachyus growing in the same community.

Table 4 shows the TNC contents of whole $90 \%$ green plant and whole yellow plants. The green plants contain significantly higher

Table 4. Total nonstructural carbohydrates in native grasses.

\begin{tabular}{|c|c|c|c|}
\hline Species & $\begin{array}{l}\text { Whole plant } \\
90 \% \text { green }\end{array}$ & $\begin{array}{l}\text { Whole plant } \\
100 \% \text { yellow }\end{array}$ & LSD 0.05 \\
\hline & \multicolumn{2}{|c|}{$\ldots$} & \\
\hline Panicum turgidum & 12.4 & 7.7 & 1.6 \\
\hline Hyperrhenia hirta & 8.2 & 5.2 & 1.5 \\
\hline Andropogon distachyos & 8.0 & 5.2 & 0.8 \\
\hline Stipagrostis plumosa & 8.2 & 5.1 & 0.8 \\
\hline LSD $0.05=$ & 1.3 & 0.6 & \\
\hline
\end{tabular}

TNC than the yellow plants. Even the yellow plant TNC contents are quite comparable to that of many range plants (Trlica 1981, Bokhari 1978). P. turgidum plants contain significantly more TNC than the other species. It appears that $P$. turgidum possessess all the characteristics necessary for its adaptation to a wide range of soil and climatic conditions and this may be one of the reasons for its occurrence in contrastingly heterogencous climatic zones in the Kingdom. Almost all the species in this study contain relatively high TNC as a source of energy for survival following grazing or under adverse climatic conditions brought about by drought or high temperatures. The high TNC content in dry plants serves as a source of reserve food materials and also provides materials rich in energy to grazing animals.

Table 5 gives the data for TNC in different parts of the plant. The stems of $P$. turgidum (nodes plus internodes) contain significantly

Table 4. Nonstructural carbohydrates of different parts of native grasses.

\begin{tabular}{|c|c|c|c|c|c|c|c|}
\hline Species & Leaves & Stem & Roots & Crown & Nodes & $\begin{array}{l}\text { Inter- } \\
\text { nodes }\end{array}$ & $\begin{array}{r}\text { LSD } \\
0.05\end{array}$ \\
\hline Panicum turgidum & 9.2 & 10.1 & 7.3 & 6.6 & 8.0 & 4.3 & 0.9 \\
\hline Panicum hirta & 7.2 & 5.5 & 5.4 & 4.6 & 3.0 & 2.0 & 0.5 \\
\hline Andropogon distachyos & 5.5 & 4.2 & 3.2 & 2.9 & 2.2 & 1.6 & 0.5 \\
\hline Stipagrostis plumosa & 5.2 & 4.0 & 4.0 & 2.5 & 1.8 & 2.0 & 0.7 \\
\hline LSD 0.05 & 0.8 & 0.6 & 0.8 & 0.6 & 0.8 & 0.5 & \\
\hline
\end{tabular}


more TNC than the other parts except TNC in leaves, which are not different from the TNC in stems.

Nodes contain almost the same amounts of TNC as the roots, but significantly more than the internodes. Similar to roots, and crowns, nodes also serve as food storage organs for regrowth, if propagated while they are still alive. Nodes of $P$. turgidum produce many auxiliary branches during the growing period. In other species, nodes contain less TNC than roots or crowns, which shows that in these species the below-ground parts are the major storage organs.

Both protein and TNC in all the species studied accumulate in substantial quantity during current growing period. The TNC contents in these plants are comparable to those of other grasses from different locations (Holt and Hilsi 1969, Mcllory 1967, Perry and Moser 1974, Bokhari 1978, Menke and Trlica 1981).

Many desert plants over the years have developed strategies of both morphological and physiological nature to cope with the harsh environment of the desert (Bokhari et al. 1987). Under favorable moisture conditions, these rich sources of reserve materials are utilized for fast vegetative growth to take advantage of the short duration of the rainy season. During this period, these plants develop sufficient photosynthetic surface in a short time to utilize the available resources of moisture, high temperature and irradiance. Photosynthetic rates are much higher during vegetative stage than the flowering stage (Bokhari et al. 1987) resulting in accumulation of substantially greater amounts of reserve food materials in various parts of the plants. It appears from this study that during the growing period, both the source of photosynthate and the sinks for photosynthate are able to generate and accumulate large quantities of reserve food materials.

Although much of the photosynthate from the current year's growth is channeled to the storage organs, and very little is utilized for biomass production, it still provides substantial green biomass for grazing animals. The pastoral grazing system in Saudi Arabia, developed over the years as a result of necessity, provides some relief to rangelands due to the nomadic life of the Bedouins who continue searching for better grazing areas throughout the year. In some areas, where the movement of grazing animals is restricted due to terrain or social constraints, the range conditions are deteriorating. Improvement of these rangelands is very difficult, if not impossible, due to very low annual rainfall, except in the southwestern region.
By understanding the perpetual survival mechanism of the rangeland plants we will be able to develop plans for improvement of arid rangelands. Species with characteristics similar to these, but with potential for high productivity should be studied in detail in pilot studies throughout the Kingdom. Genetic-blending between native and introduced species within similar taxonomic groups, followed by selection for favorable characteristics, may provide some germplasm for improvement of rangelands.

\section{Literature Cited}

Bokhari, U.G. 1978. Total nonstructural carbohydrates in the vegetation components of a shortgrass prairie ecosystem under stress conditions. J. Range Manage. 31:224-230.

Bokhari, U.G., F. Alyaeesh, and M. Noori. 1987. Adaptive strategies of desert grasses in Saudi Arabia. J. Range Manage. 40:19-22.

Coward-Lord, J., J.A. Arroyo-Aguilu, and O. Garcia-Molinari. 1974. Proximate nutrient composition of 10 tropical forage grasses. J. Agr. Univ. Puerto Rico. 18:305-311.

Fischer, R.A., and N.C. Turner. 1978. Plant productivity in the arid and semiarid zones. Annu. Rev. Plant Physiol. 29:277-317.

Handy, A.H., and R.A. Tucker. 1984. Rainfall quality at selected sites in Saudi Arabia. Ministry of Agriculture \& Water, Water Research \& Studies Division. Pub. 2. p. 27.

Holt, A.A., and A.R. Hilst. 1969. Daily variation in carbohydrate content of selected forage crops. Agron. J. 61:239-242.

Mcllory, R.J. 1967. Carbohydrate of grassland herbage. Herbage Abst. 37:79-87.

Menke, J.W., and M.J. Triica. 1981. Carbohydrate reserve, phenology and growth cycles of nine Colorado range species. J. Range Manage. 34:269-277.

Perry, L.J., and L.E. Moser. 1974. Carbohydrate and organic nitrogen concentrations within range grass parts at maturity. J. Range Manage. 27:276-278.

Reid, R.L., A.J. Post, and F.J. Olsen. 1979. Chemical composition and quality of tropical forages. West Virginia Univ., Agr. and Forest Exp. Sta. Bull, 669T.

Smith, D. 1969. Removing and analysing total nonstructural carbohydrates from plant tissue. Res. Rep. 41. Res. Div., Univ. Wisconsin, Madison.

Vessey-Fitzgerald, D.F. 1957. The vegetation of central and eastern Arabia. J. Ecol. 45:779-798.

Yadava, P.S. 1980. Distribution and cycling of nitrogen in soil-vegetation components of tropical grassland. Trop. Ecol. 21:24-31.

Zahran, M.A. Vegetation types of Saudi Arabia. Faculty of Meteorology \& Environmental Studies, King Abdulaziz Univ., Jeddah, Saudi Arabia.

\section{Moving?}

If you are changing your address, notifying the post office is not sufficient to keep your journal coming on time. Please send your new address and the label with your old address to the Society for Range Management, 1839 York Street, Denver, Colorado 80206, USA. 